\title{
BRICS AND CLICKS
}

\author{
Mary Bold, Ph.D., CFLE, Associate Professor \\ Lillian Chenoweth, Ph. D., Professor \\ Nirisha K.Garimella, M. Sc., M. S. \\ Family Studies at Texas Woman's University
}

\begin{abstract}
Projections for the global economy frequently center on the BRIC countries: Brazil, Russia, India, and China. As futurists and economists alike define and re-define both formal and informal coalitions (for example, by broadening the R in BRIC to include all Eastern European economies or instead re-directing the discussion to G-8 countries or to World Trade Organization members), the education profiles of the individual nations sometimes resemble economic indicators: what is imported, what is exported, and what is the potential for expansion. Higher education, and specifically distance learning (the Clicks element of this paper), can already be charted in these terms for some nations. This paper describes the current role of distance learning in countries described as growing economies and proposes a typology for describing change as additional data become available. The paper informs readers of global developments in distance education, using the BRIC nations as examples.
\end{abstract}

\section{KEYWORDS}

Cross-Border Education, Globalization, BRIC, GATS, Internationalization, Distance Learning, Access, Right to Education

\section{INTRODUCTION}

The global perspective for education is decades old: the globalization of scholarship was named by the 1970s. From the 1960s, research and public service in international settings were foci for higher education [1]. Today's perspective may be described more commercially: the globalization of enrollments. But many of the same ideals persist: extending access to education to the world's citizens, preparing all students for internationalization, and sharing resources for the benefit of developing countries.

Distance learning is the new player in a global concern: the right to education. Educational rights have been the center of many initiatives in past decades. Organization supports such as UNESCO's promotion of Education for All (EFA) date to 1990 at the World Conference on Education for All. With updates in 2000 and 2001, progress has been charted for this initiative for universal primary education [2]. Commonly, nations have set their own agendas for increasing access to education, typically emphasizing universal education for their youngest citizens. But access to higher education has also generated government initiatives as countries have sought to meet growing demands for both higher education and for adult education [3]. Traditional, formal education continues to dominate national initiatives, but distance learning is recognized as the route for expansion of systems and access by learners [4]. Obvious results of this recognition are the emergence of mega universities, open universities, branch campuses by foreign institutions either operating singularly in a host country or in partnership with a local university, and cross-border education. Each of these routes to access will be discussed. 
How the right to education (as a movement) will develop in the current century surely will be tied to global economics just as much as to the advancement of technology. At first glance, we make assumption that an individual's right to education will depend on decision to access a source of education, acquisition of technology to support that decision, and presumably some commitment of personal finances to accomplish these things. At second glance, we realize that the right to education demands an infrastructure of technology, financial supports, and government supports beyond the individual's influence.

\section{SCOPE OF ONLINE EDUCATION}

Bourne, Moore, Sener, Mayadas, and Ettinger [5] predicted that two billion people worldwide might be identified as learners, assuming that global access to education will eventually resemble the widespread access in the United States. The basis for the prediction is the estimate of one-third of the U.S. population taking part in education, from young children through adult learners. In market terms for higher education, online delivery may exceed US\$69 billion by the year 2015 [6].

How many of two billion learners may find their access to education through online delivery channels is not known, of course, and depends on many factors, including access to the Internet and other networks, teaching workforce (whether in country or cross border), curriculum development, learner readiness and interest in distance learning, and amount of technology equipment in the hands of learners.

Among Asian countries, smaller land mass is associated with higher Internet penetration [6]. China and India, large in size both geographically and demographically, face a huge challenge in connecting the population to networks across their land mass. China has the largest number of Internet users in the world, nonetheless. Access networks within countries are exemplified by Canada's Contact North/Contact Nord, which links 90 access centers throughout rural Northern Ontario and thus offers higher education courses and degrees to a population that had few options previously [7, 8]. The investment in technology infrastructure is a major factor in providing access to distance learning, and it necessarily involves decisions about how technology is regulated and supported by governments.

Regulation, or a network of regulations, is a logical expectation for global education initiatives, whether they emerge from public or private institutions. How coordinated those regulations turn out is a complex and worrisome issue. But globalization across many fields has demonstrated to us the effects of interdependence among nations, effects anticipated and those not anticipated.

Support for infrastructure by governments can literally mean the structure of networks. China's CERNet (China Education and Research Network) was constructed in 1995 and was largely responsible for a collaborative project between Chinese and European universities that would span the years 1995 to 2002 [9]. The NCEC project, Network-Training Collaboration in Europe and China, pioneered a EuropeanAmerican model of Internet-based learning for China that included XML-based curriculum design and learning objects repositories. NCEC goals were to develop network-based course production/delivery and to improve utilization of the Internet. As CERNet and the Internet in general stimulated demand for the Internet, the Chinese government has increased its investment in expanded access. NCEC collaborators credited end-user Internet access as key to project success and the continued success of distance learning in China. Specifically, the collaborators cited these factors that deliver the Internet in the "last mile," to the end user: dial-up access since 1998 and ISDN services in major cities since 2000, affordable broadband Internet cafes in nearly every town, and broadband access in homes since 2001 via DSL (US\$3.50/month under 3-year contract) and cable modem (approximately US\$11/month). These 
examples from the NCEC project shore up Keegan's [10] contention that ultimately the success of distance learning depends on users having access tools in their possession or within easy reach.

Contrasting the report on end user access, however, is the pragmatic question of the quality of the connection to the Internet. Technical evaluation into loading speeds of webpages presents a challenge not often reported with access statistics. Baggaley and Batpurev [11] reported slow speeds (up to four times slower than acceptable rates of page opening) and frequent failures to open webpages at all. Best response time was noted for locally hosted materials that had been created in either the Docebo or Moodle learning management system (LMS). A follow-up study took traceroute measurements to identify how many "hops" an Internet missile makes from origin to destination; the researchers concluded the range was from simple to extremely complex [12]. Among tests for 12 Asian countries, a Pakistan network provided the most direct delivery, and a Chinese missile required 18 hops across the globe (including to the U.S.) to land in another Asian country. Baggaley and Batpurev recommended that checks on browsers' speed of opening online materials become a usual part of formative evaluation for distance learning courses. They concluded that most programs do not make such checks, and that students may not make a report on slowloading materials. Thus, producers of online curricula do not have good reports on the use of their works.

\section{CROSS-BORDER DELIVERY OF ONLINE EDUCATION}

Might those nations with extensive online networks serve other nations in online education delivery? Indeed, as articulated by a group of international and U.S. organizations, cross-border offerings should specifically assist developing countries and thus "promote global equity" [13]. Bourne et al. [5] named economic barriers as a reason we might not see expansion in this direction; however, the amount of crossborder delivery of education will be appreciable, even if growth rates were to be modest. Certainly, the U.S. and the U.K. are host to large numbers of international students who travel for higher education, especially graduate degrees. In the past generation, traveling to a new country for higher education has more than quadrupled [14], and the trend for traditional travelling students is upward bound, estimated to increase from 2.5 million in 2004 to 7.2 million by 2025 [15]. British universities have seen recent growth in their number of international students [16], with expectation for increasing numbers due to expanded recruitment [17]. Distance learning is also an option for international students seeking U.K. course work or programs, greatly reducing costs and travel requirements for students $[16,18]$. The U.S. is the leading exporter of education; Hezel and Mitchell [6] estimated that the U.S. serves one-third of the world's students engaged in cross-border education. MacLeod and Ford [19] related the many shifts in exporting education (including some of the more famous failures by American universities) but pointed out strong showings by Australian universities and the UK Open University, and strong prospects for Chinese and Indian open universities. Similarly, Jung [20] identified other exporters as Hong Kong and Malaysian universities, the U.S. for-profit entity University of Phoenix, and the Indira Gandhi National Open University. In short, the number of exporters of education is growing.

Referring to a country as an exporter of educational services is not accidental. The prospect of distance learning itself as an economic indicator results from World Trade Organization (WTO) negotiations to name education as a marketable service, subject to import and export regulations. Proposals regarding higher education, distance learning included, have worked their way through General Agreement on Trade and Services (GATS) proceedings since 2000. For educational services that do not involve physical movement by the consumer, the term cross-border supply is used to cover distance education, e-learning, and virtual universities. A growing market, cross-border supply is recognized as having great potential [3]. 
GATS introduces services exclusively (in contrast to products) as the subject for trade agreements, with 12 sectors addressed. The sector for education services has drawn criticism as proposals have been offered by countries seeking to promote freer trade and expand transnational education [21, 22, 23]. Each country in the WTO can specify its own agreement and therefore maintain certain controls over how education services may be imported. The common theme is to increase access to education but proponents and critics suggest very different scenarios on the issue. Proponents of GATS point to cross-border supply as having great potential for inexpensive schooling via electronic and Internet delivery.

Critics warn that GATS will spur the growth of for-profit institutions, weaken quality of distance learning offerings, and generally drive a more commercial approach to higher education $[2,23]$. Concerns include how trade policy may affect the academic and research activities central to institutions' missions and conflict with education's typical purpose to serve the public interest. Sorensen [24, p. 8] described the reaction of educational entities to GATS as "consecrating education as a tradable commodity and betraying the tradition of education as a common good.” Sorensen recommended an expanded role for international forums such as UNESCO and OECD to address the issues.

\section{QUALITY ASSURANCE}

Concerns of quality assurance and specifically diploma mills continue to dog the debates about GATS and about distance learning in general [23]. The development of the Internet places many of those problems in the U.S., simply because American universities often have been leaders in specific teaching technologies [24]. Thus, some web-based fraud such as plagiarism is on the rise across most institutions, most countries. But there does appear to be a relationship between fraud and an institution's economic standing. Pressure to increase enrollment may lead to irregular admissions standards or practices and the institution's employees may also seek personal gain for practices that produce more students [25].

Internationally, the assurance of a degree's soundness must pass tests of quality, accreditation, comparability, and students' prerequisite qualification. Principles of accountability have been endorsed by leading accreditors, specifically naming cross-border higher education and calling for faculty and student involvement in quality assurance processes [13]. Increased attention to accreditation and outcomes evaluation of education can be seen worldwide. Standardized tests of critical thinking, mathematics, and writing are designed for use across nations at the university level. Jung [20] pointed out that all mega universities (distance learning institutions with enrollments over 100,000) now provide for some type of quality assurance, and more than half of them also provide staff development for faculty and staff.

Quality assurance has thus become an international conversation, not just a within-nation concern. Ding [26] described a long-standing perception in China that distance learning is of lesser quality than campus learning, with one factor being that admission to a distance university may reflect low admissions scores that blocked entry to a traditional campus. In spite of the long 80-year history of distance education in that country, the persistent interpretation is that students cannot attend other schools, even though many students do have work and family reasons for having chosen distance education. Ding's research found that students in Chinese distance learning often begin their studies feeling inferior to peers on traditional campuses but quickly build their confidence in the quality of their education. The Chinese government holds the degrees as comparable regardless of delivery, and distance programs are recognized as qualifiers for advanced degrees. This is not a guarantee, however, as admissions to graduate study rely on standardized test scores, not grades. Ding's subjects called for public discourse about the legitimacy of education from distance learning institutions and also pointed to a key factor in young adults' attitudes: what high school teachers communicate about quality education. At present, that communication is not positive about distance learning, highlighting how embedded the attitudes are. 
How quality assurance is to be addressed in this international conversation requires leadership. Daniel et al. [27] suggested that this is the work of UNESCO and the OECD, to shape "supranational” policy, taking into account the diverse needs and requirements of participating nations. Provisions in the Guidelines for Quality Provisions in Cross-Border Higher Education [28] may be adequate although they have sparked debate among stakeholders who question whether all interests and participation, including faculty's, are represented. With the variety of stakeholders and expectations across nations, quality assurance standards are not automatic.

Whether such assurance can emerge from the marketplace is just one question. More fundamentally, critics of GATS ask if the trade policy arena is the correct setting for the question. Altbach [29, p.2] described the co-modification of education in terms of the "broader globalization agenda...probably both inevitable and unstoppable, and much of it is positive as well." Some of the negative outcomes are disregard for those academic disciplines without immediate economic pay-off (which may produce more activity in the study of business and markets, for example), competition that places home institutions at a disadvantage (especially in developing countries with fewer or less established universities), and the more than challenging prospect of tracking courses, programs, faculty, and qualified entering students in an effort to set and enforce standards of quality.

For institutions seeking to provide cross-border education, Green and Baer [30] posed compelling questions about how the provider's entrepreneurial goal of enrolling students from or in another country might be aligned with its mission and academic activity on its own campus. Does the institution articulate global learning as a goal for its own undergraduates? Are global perspectives included in the general education curriculum and are faculty rewarded for integrating perspectives in their teaching and scholarship? Do the institution's and faculty member's international activities impact the students? Are exported distance learning courses relevant for an international audience or do they merely reflect conversion to a new delivery mode? Daniel [27] posed this same question with specific examples: will cross-border providers meet each country's priorities, such as tourism management for the West Indies and conflict resolution for Sierra Leone? These locales are better served by their local universities than by foreign providers that more frequently deliver what they already have developed.

GATS updates in 2007 continue to promise action. Most commentators expect that finalizing the trade agreements for education will take several more years. In the meantime, as higher education leadership articulates high standards for cross-border education, it can be hoped that the continuing trade formulations take heed. For example, a 2005 cooperative statement on Cross-Border Higher Education was issued by these HE institutions and providers: International Association of Universities (IAU), Association of Universities and Colleges of Canada (AUCC), American Council on Education (ACE), and Council for Higher Education Accreditation (CHEA). Their joint statement included these five areas for standards:

- Constructive dialog between associations and governments regarding education and trade issues

- Culturally sensitive education that contributes to the host country's social and economic wellbeing as well as strengthens local higher education capacity

- Improved access for qualified students with financial need

- Authorization to operate from both the home and host countries

- Culture of ongoing quality review, feedback, and improvement

While access is typically described in positive terms, the growth of higher education worldwide has made obvious the circumstances by which access is compromised on ethical terms. Hallak and Poisson said 
multiple sources report that "Russian citizens pay annually up to US\$520 million in bribes" for entry to higher education [25, p. 79]. Hallak and Poisson's extensive review of corruption in education cites abuses beyond the former countries of the Soviet Union. Hallak and Poisson concluded that, "admission to universities is entirely corrupt in some parts of the world.... Moreover, academic fraud has developed into a real industry in some places such as the United States, with Internet-based firms now selling research papers and fake diplomas" [25, p. 240]. Academic fraud is found in all these forms: examinations, admissions, diplomas.

Current solutions to unethical access hold promise for the future. Hallak and Poisson [25] cite examples from these BRIC nations:

- China employs strict measures against cheating on examinations, such as one-year disqualification for copying and three-year disqualification for attempting impersonation by a test-sitter.

- Former Soviet states now use admission exams overseen by an independent organization.

- India addressed transparency and accountability through the enactment of right to information legislation.

Returning to our basic discussion of right to education, our current knowledge of quality assurance globally would suggest that an important qualifier is needed: the learner's right to quality education. How quality is measured and eventually assured publicly can develop in many different ways. What is remarkable from a global perspective is that the emergence of low-quality education (in addition to diploma mills that provide no education) is universal.

\section{OPEN UNIVERSITIES}

Open universities are often the largest higher education institutions in their countries. As a group, open universities serve millions of students, using distance learning as the main delivery system [29] but not all offerings are Internet-based or even electronic in nature. Rather, the mix of methodologies is varied and includes self-paced instruction through print materials delivered by post. The modern connotation is, increasingly, that degree programs are delivered through the Internet but even these may involve face-toface meetings or periodic in-person testing.

The implicit meaning of the term "open," for hundreds of thousands of students, is the U.K. Open University, frequently referred to as simply OU. Founded in 1969, the first students were admitted in 1971. Growth was immediate and OU is frequently cited now as comprising the U.K.'s largest university besides serving as a model for open universities worldwide. Besides being drawn by the open admissions policy, students come for the convenience of radio- and television-broadcast courses, online courses, and compact summer school sessions. With enrollments surpassing 180,000, the OU also qualifies as a mega university.

\section{Open Universities:}

- Allama Iqbal Open University, Islambad, Pakistan

- Athabasca University - Canada’s Open University

- China Central Radio and TV University, Beijing, China

- $\quad$ Dutch Open Universiteit, Nederland
- Indira Gandhi National Open University, New Delhi, India

- Institut Teknologi Mara, Kuala Lumpur, Malaysia

- Korea Air and Correspondence University, Seoul, Korea

- Korea National Open University, Seoul, Korea 
- National Open University, Taiwan, China

- $\quad$ Open Learning Institute of Hong Kong, Hong Kong SAR, China

- Open University of Catalonia

- Open University of Hong Kong, Hong Kong SAR, China

- Open University of Israel

- Open University Malaysia, Jula Lumpur, Malaysia

- $\quad$ Open University of Sri Lanka, Colombo, Sri Lanka
- Payame Noor University, Tehran, Iran

- Shanghai TV University, Shanghai, China

- Sukhothai Thammathirat Open University (STOU), Bangkok, Thailand

- U.K. Open University, United Kingdom

- University of Philippines Open University, Manila, Philippines

- Universitas Terbuka, Jarkarta, Indonesia

- University of the Air, Tokyo, Japan

\section{MEGA UNIVERSITIES}

The so-called mega-universities are literally defined by their size: enrollments of more than 100,000 [27, 31]. Extra large units boast enrollments of 500,000 such as that seen at Anadolu University in Turkey. Self-reports in a 2004 survey of selected mega universities [32] suggested even higher figures of more than one million students attending India's IGNOU and more than two million attending China's CCRTVU. Table 1 identifies mega-universities by country, providing name and abbreviation. The year of an institution's establishment clearly may predate the distance learning technology that dominates (and makes possible) the growth of these institutions today.

While mega universities' economies of scale reduce the budgeted cost per student [31], large enrollments make their management challenging. A high growth rate, such as Iran's PNUs, would demand procedural and policy shifts to accommodate the additional students. In the case of PNU, the enrollment growth was dramatic: from 5000 in 1988 to 117,000 in 1996. To most observers in higher education, that would be called an overnight transformation to mega university status and one that does not reflect usual growth. Daniel explained a demographic change during that time span: the government exempted young adults from military service during their studies and commissioned them as officers afterward [31, p. 179]. Thus, the socio-historical context for growth deserves mention, just as does a view on trade-off's for growth. Typically, that trade-off is expected to be in quality control.

Daniel, et al. [27] proposed that mega universities can undertake rigorous quality assurance measures and can achieve high ratings. Citing experience with his own institution, the U.K. Open University, Daniel advised that high standards can be maintained and student satisfaction can exceed that of traditional campuses. Jung's [32] report on survey results from mega universities concluded that most of the institutions utilize quality assurance systems, some being rigorous with external reviews and some extending activities to providing professional development for faculty and staff. Two institutions reported using quality assurance measures for cross-border education; most of the mega universities have not needed to assess imported/exported education. Similarly, few institutions had provided for separate evaluation for distance learning, instead using the same methods for all forms of delivery. Turkey's and India's universities had created processes as well as separate evaluation agencies for addressing quality of distance learning courses. 


\begin{tabular}{|c|c|c|c|c|}
\hline Country & Institution & Established & Abbreviation & Source \\
\hline Bangladesh & Bangladesh Open University & 1992 & $\mathrm{BOU}$ & UNESCO, 2005 [33] \\
\hline Canada & Athabasca University & 1970 & $\mathrm{AU}$ & UNESCO, 2005 [33] \\
\hline \multirow[t]{2}{*}{ China } & $\begin{array}{l}\text { China TV University System } \\
\text { AKA China Central Radio and } \\
\text { TV University }\end{array}$ & 1979 & $\begin{array}{l}\text { CTVU } \\
\text { or } \\
\text { CCRTVU }\end{array}$ & $\begin{array}{l}\text { Daniel, 1998, [31, p. 30]; } \\
\text { UNESCO, } 2005 \text { [33] }\end{array}$ \\
\hline & Shanghai TV University & & SHTVU & Jung, 2005 [32] \\
\hline France & $\begin{array}{l}\text { Centre National } \\
\text { d'Enseignement à Distance }\end{array}$ & 1939 & CNED & Daniel, 1998, [31, p. 30] \\
\hline Germany & Fern University in Hagen & 1974 & & UNESCO, 2005 [33] \\
\hline India & $\begin{array}{l}\text { Indira Gandhi National Open } \\
\text { University }\end{array}$ & 1985 & IGNOU & Daniel, 1998 [31, p. 30] \\
\hline \multirow[t]{2}{*}{ Indonesia } & Universitas Terbuka & 1984 & UT & Daniel, 1998 [31, p. 30] \\
\hline & $\begin{array}{l}\text { Indonesian Open Learning } \\
\text { University }\end{array}$ & & & UNESCO, 2005 [33] \\
\hline Iran & Payame Noor University & 1987 & PNU & $\begin{array}{l}\text { Daniel, } 1998 \text { [31, p. 30]; } \\
\text { UNESCO, } 2005 \text { [33] }\end{array}$ \\
\hline Korea & $\begin{array}{l}\text { Korea National Open } \\
\text { University }\end{array}$ & $\begin{array}{l}\text { 1982, as the } \\
\text { Korea Air and } \\
\text { Corresponden } \\
\text { ce University }\end{array}$ & KNOU & Daniel, 1998 [31, p. 30] \\
\hline \multirow[t]{2}{*}{ Mexico } & $\begin{array}{l}\text { Instituto Tecnológico } \\
\text { Autónomo de México }\end{array}$ & 1946 & ITAM & UNESCO, 2005 [33] \\
\hline & $\begin{array}{l}\text { Universidad Nacional } \\
\text { Autonoma de Mexico }\end{array}$ & 1910 & UNAM & UNESCO, 2005 [33] \\
\hline Pakistan & Allama Iqbal Open University & 1972 & $\mathrm{AIOU}$ & UNESCO, 2005 [33] \\
\hline South Africa & University of South Africa & $\begin{array}{l}1873 \text { as the } \\
\text { University of } \\
\text { the Cape of } \\
\text { Good Hope }\end{array}$ & $\begin{array}{l}\text { UNISA } \\
1 / 3 \text { of country's } \\
\text { enrollments in } \\
1995\end{array}$ & Daniel, 1998 [31, p. 30] \\
\hline South Korea & $\begin{array}{l}\text { Korea National Open } \\
\text { University }\end{array}$ & 1972 & KNOU & UNESCO, 2005 [33] \\
\hline Spain & $\begin{array}{l}\text { Universidad Nacional de } \\
\text { Educacíon a Distancia }\end{array}$ & 1972 & UNED & $\begin{array}{l}\text { Daniel, } 1998 \text { [31, p. 30]; } \\
\text { UNESCO, } 2005 \text { [33] }\end{array}$ \\
\hline Thailand & $\begin{array}{l}\text { Sukhothai Thammathirat Open } \\
\text { University }\end{array}$ & 1978 & STOU & $\begin{array}{l}\text { Daniel, } 1998 \text { [31, p. 30]; } \\
\text { UNESCO, } 2005 \text { [33] }\end{array}$ \\
\hline Turkey & Anadolu University & 1982 & $\mathrm{AU}$ & $\begin{array}{l}\text { Daniel, } 1998 \text { [31, p. 30]; } \\
\text { UNESCO, } 2005 \text { [33] }\end{array}$ \\
\hline \multirow[t]{3}{*}{ U.S.A. } & City College of San Francisco & 1935 & CCSF & UNESCO, 2005 [33] \\
\hline & $\begin{array}{l}\text { University of Maryland } \\
\text { University College }\end{array}$ & 1947 & UMUC & UNESCO, 2005 [33] \\
\hline & University of Phoenix & 1976 & & UNESCO, 2005 [33] \\
\hline United Kingdom & The Open University & 1969 & UKOU & $\begin{array}{l}\text { Daniel, } 1998 \text { [31, p. 30]; } \\
\text { UNESCO, } 2005 \text { [33] }\end{array}$ \\
\hline
\end{tabular}

Table 1. Mega Universities Worldwide

\section{PREDICTORS FOR SUCCESSFUL ONLINE DELIVERY}

A key predictor for successful online delivery is the ability for "scaling," or growing programs to accommodate large numbers of learners. Examples in the U.S. reviewed by Moloney and Oakley [34] suggest several conditions common to online programs that have successfully grown to service hundreds of students in a single program. Chief among the conditions is alignment of institutional mission with the 
program purpose of online delivery. Articulating the intent to reach populations through distance learning establishes a goal that is readily understood by all stakeholders, from top administration to the newest student and including the staff that may be campus-bound but crucial to the success of students who never come to campus. Technology infrastructure must be in place, of course, and assumes the ability to connect to and access the Internet or other networks.

Successful delivery finally depends on what technologies learners have in hand. PDA and cell phone modes have been demonstrated to facilitate distance learning, and some universities have reported even whole courses delivered through these mobile learning devices [10]. Additionally, print materials delivered through postal mail can be supplemented with text messaging through mobile phone, PDA, and email technology.

On the program level, scaling has proved most successful when a well-identified set of courses is offered as a whole program, whether for certificate or degree. Efficiencies for educational institutions include faculty and staff training that is utilized numerous times, investments in infrastructure that serve for multiple applications (including traditional on-campus education), and recruiting of students who will enroll consistently for the span of time represented by the degree program.

Reports of pedagogical success increasingly cite a constructivist approach in distance learning [4]. Global change in education since the inception of the Internet was documented in 2002 by the Second Information Technology in Education Study Module 2 (SITES-M2), a qualitative and comparative analysis coordinated by the International Association for the Evaluation of Educational Achievement (IEA) [35]. The IEA study established the impact of information and communication technologies in 2000-2001 on primary and secondary schools in 28 countries [35].

\section{STANDARDS FOR COMPARISONS}

Published statistics on access to education and access to distance learning are not easily compared. For example, an NCES report [36] on higher education in G-8 countries (Canada, France, Germany, Italy, Japan, Russian Federation, United Kingdom, and United States), was unable to report statistics for all countries for all indicators. Similarly, the statistics reported in this paper for BRIC nations are far from comprehensive, and individual elements may not be genuinely comparable.

Seeking consensual meanings across borders is a challenging pursuit, one that relies heavily on international standards, frequently advanced by professional, scholarly, or government communities. Higher education is described by ISCED levels: International Standard Classification of Education. "ISCED 1997" is the current system, based on a foundational taxonomy proposed by UNESCO in the 1970s [37]. This classification system does not attempt to compare cultures; rather, the system provides a statistical framework for comparability along two categories: education levels and education fields. As revised in 1997, ISCED acknowledged "distance education and other modalities based on new technologies” as trends that demanded accommodation by the system [37].

Another scheme for classification is the United Nations' Provisional Central Product Classification (CPC) system. Five categories are represented: Primary Education (CPC 921), Secondary Education (CPC 922), Higher Education (CPC 923), Adult Education (CPC 924), and other education (CPC 929) [38].

Vetting educational statistics is addressed by the Data Quality Assessment Framework (DQAF), a means 
for qualitative assessment as proposed by UNESCO's Institute for Statistics (UIS) and the World Bank [39]. Briefly, the DQAF calls for integrity of data, methodological soundness, accuracy, reliability, serviceability, and accessibility. That such a framework has been developed speaks to the need for global statistics. The framework will promote understanding of education in the world today.

\section{LEXICON FOR INTERNATIONAL EDUCATION}

Borderless education: The provision of educational service in any one of four modes: cross-border (student is in own country, accessing schooling through the Internet or other technology), consumption abroad (student moving to a country for school), commercial presence (student accesses schooling in own country at a satellite campus or partnering institution), presence of natural persons (student receives service in own country from a visiting educator) [3].

Compulsory education: Span of time that students are legally required to attend school [39].

Cross-border education: Mode of education for the student in his or her own country to access schooling from across a border, typically through the Internet or other technology.

Globalization: AKA internationalization.

Higher education: Post-secondary education that follows all compulsory levels of education in a country.

ICT: Information and communication technologies.

Internationalization: Perspective of societal, economic, and cultural processes on a global scale and one that expects a worldview to account for the diversity of peoples.

Mega University: Term coined by Sir John Daniel in the mid-1990s to refer to a large institution that offers primarily distance learning and enrolls more than 100,000 students. Worldwide, eleven are commonly recognized in this category.

Mobile Learning: Use of mobile communications devices such as cell telephones and PDAs, which increasingly offer adequate screen size for display of course materials or, at the least, texting for announcements, assignments, and alerts for upcoming lessons in other modes.

Open/Distance Learning: Highly accessible education delivered across distance and, increasingly, meant to reflect electronic and Internet-based delivery.

Open University: Institution that has a more open admissions policy, often permitting entry by adults who do not have traditional qualifications for higher education. Delivery of course work increasingly relies on electronic or Internet-based communication technology. Based on the model of the U.K. Open University; some usage clearly identifies that single institution as the meaning of the term.

Pseudouniversities: Term coined by Philip Altbach in 2001 to refer to for-profit institutions that market 
programs in high profit disciplines and claim the label of university without providing the range of scholarship and disciplines typically reflected by the term [1].

School Life Expectancy: Average duration of a child's education from age 5 onward; global comparisons rarely account for the great variety of factors such as full-time versus part-time attendance, number of months per year in school, and whether repeated grades are reflected.

Tertiary Education: (ISCED) Type A, leading to baccalaureate and higher degrees; Type B, shorter programs (2 to 3 years) focused on work force entry.

Transnational Education: Frequently used to mean cross-border, indicating that student or delivery of education crosses national lines.

\section{BRIC STATISTICS}

UNICEF (n.d.) provides statistics on all of the BRIC nations as noted in Table 2 for years 2004 and 2005. Three of the BRIC nations-Brazil, China, and the Russian Federation-are represented in statistical gathering of World Education Indicators (WEI or WEI Programme), as indicated for years up to 2003. The WEI Programme includes 16 other countries, as well, for what the sponsoring organizations call coverage of "over $70 \%$ of the world's population” [41].

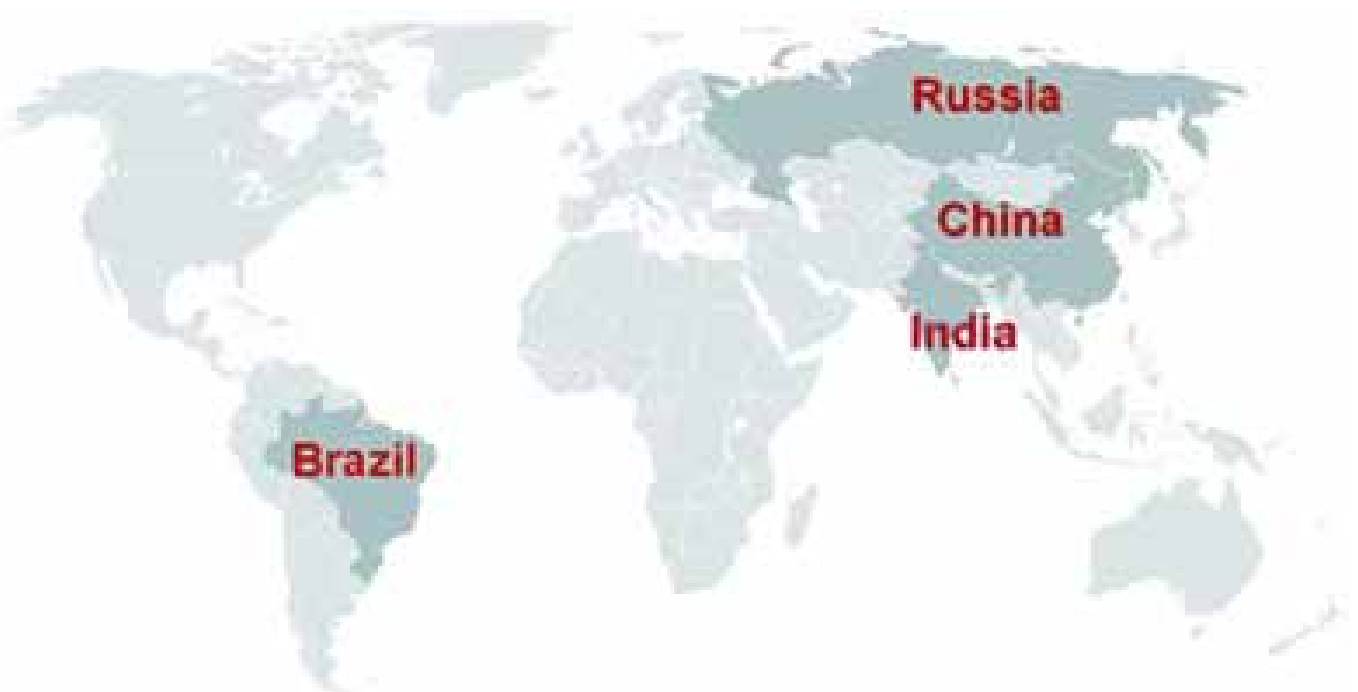

Figure 1. The BRIC Nations of Brazil, Russian Federation, India, and China are Recognized as the Next Leading Forces in the Global Economy.

\begin{tabular}{|l|l|l|l|l|}
\hline & Brazil & Russian Fed. & India & China \\
\hline $\begin{array}{l}\text { Average school life } \\
\text { expectancy (a) }\end{array}$ & 16.1 years & & 9.8 & \\
\hline $\begin{array}{l}\text { Recent increase in the } \\
\text { above statistics (b) }\end{array}$ & 2 years & More than doubled & $\begin{array}{l}\text { Increased more } \\
\text { than 50\% }\end{array}$ & More than tripled \\
\hline $\begin{array}{l}\text { Recent growth in tertiary } \\
\text { education, type A programs } \\
\text { and advanced research } \\
\text { study (b) }\end{array}$ & Doubled & & & \\
\hline
\end{tabular}




\begin{tabular}{|c|c|c|c|c|}
\hline $\begin{array}{l}\text { Graduation rates for tertiary, } \\
\text { type } A(b)\end{array}$ & & $33 \%$ & & $5 \%$ \\
\hline $\begin{array}{l}\text { Private institutions as source } \\
\text { of tertiary education in- } \\
\text { country (a) }\end{array}$ & $\begin{array}{l}\text { Provide for } \\
\text { majority of } \\
\text { students }\end{array}$ & Very low & & \\
\hline $\begin{array}{l}\text { Gender equity females' } \\
\text { number of years in school, } \\
\text { compared to males' (a) }\end{array}$ & $>$ half-year more & $>1$ year more & 1 year less & \\
\hline $\begin{array}{l}\text { Increased expenditures on } \\
\text { tertiary education in relation } \\
\text { to enrollments (b) }\end{array}$ & Same pace & & Faster & \\
\hline $\begin{array}{l}\text { Representation of women in } \\
\text { tertiary education and } \\
\text { advanced research study (a) }\end{array}$ & $\begin{array}{l}\text { Higher (based on } \\
54 \% \text { in 1995) }\end{array}$ & $\begin{array}{l}\text { Higher (based on } \\
57 \% \text { in 2003) }\end{array}$ & $\begin{array}{l}\text { Lower (based on } \\
38 \% \text { in 2003) }\end{array}$ & $\begin{array}{l}\text { Lower (based on } \\
44 \% \text { in 1995) }\end{array}$ \\
\hline $\begin{array}{l}\text { Population in thousands in } \\
2005 \text { (c) }\end{array}$ & 186405 & 143202 & 1103371 & 1315844 \\
\hline $\begin{array}{l}\text { Total adult literacy rate in } \\
2004 \text { / for males / for } \\
\text { females (c) }\end{array}$ & $\begin{array}{l}89 \\
88 / 89\end{array}$ & $\begin{array}{l}99 \\
100 / 99\end{array}$ & $\begin{array}{l}61 \\
73 / 48\end{array}$ & $\begin{array}{l}91 \\
95 / 87\end{array}$ \\
\hline $\begin{array}{l}\text { Number of Internet users in } \\
2004 \text { per } 100 \text { (c) }\end{array}$ & 12 & 11 & 3 & 7 \\
\hline $\begin{array}{l}\text { Population annual growth } \\
\text { rate as \% 1990-2005 }\end{array}$ & 1.5 & -0.2 & 1.7 & 0.9 \\
\hline $\begin{array}{l}\text { GNI per capita in US\$ in } \\
2005 \text { [gross national income] } \\
\text { (c) }\end{array}$ & 3460 & 4460 & 720 & 1740 \\
\hline $\begin{array}{l}\text { GDP per capita average } \\
\text { annual growth rate as \% for } \\
1990-2005 \text { [gross domestic } \\
\text { product] (c) }\end{array}$ & 1.1 & -0.1 & 4.2 & 8.8 \\
\hline
\end{tabular}

Table 2. Basic Statistics for BRIC Nations

Notable statistics to help find perspective on these four nations are their populations and their number of Internet users per 1000 people. Figure 2 helps to make the information more clear. Using the statistics from Table 2, we converted the statistic for Internet penetration so that results are based on 1000 in population (from 100). The result is a startling realization of the magnitude of the numbers. We rarely take the time to visualize population statistics and, even when we do, we rarely have comparisons handy. The other realization that comes from study of the numbers is just how different the BRIC nations are. Intellectually, we know this, of course. But just the two indicators in this graphic drive home the challenge of cross-national comparisons. 


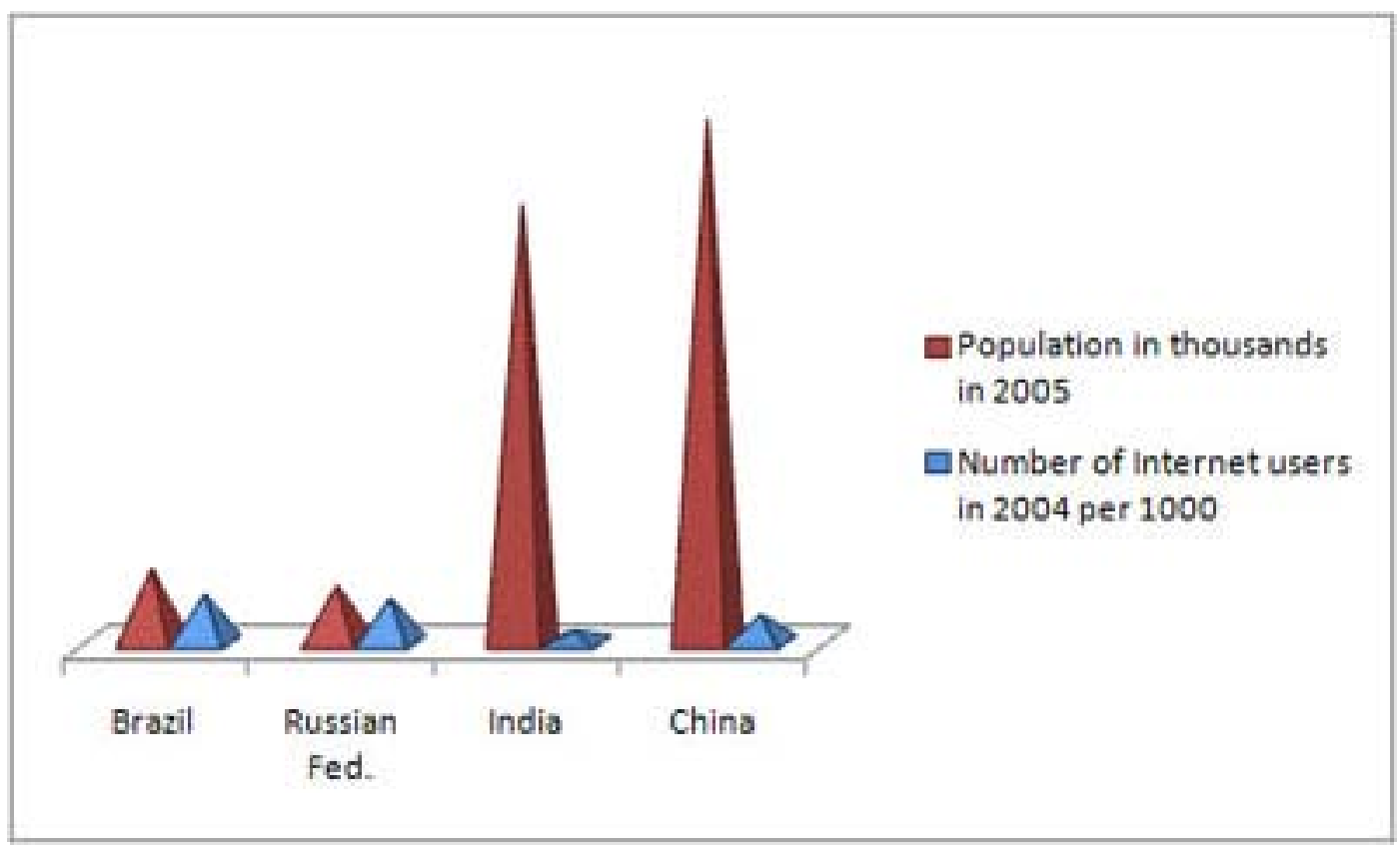

Figure 2. BRIC Nations' Populations in Thousand in 2005 and Number of Internet Users in Thousands in 2004

\section{A. Brazil}

The education system in Brazil is highly centralized [42]. Distance education, in the form of correspondence courses, has been a part of the Brazilian education realm since the early part of 1900s [42]. The demand for education combined with the physical challenges of the vast country made distance education a sound solution. The determination of the government to reach students in even the most remote regions has been facilitated through the establishment of distributed networks.

The advent of most recent change in the educational environment followed the passing of the Law of Lines and Direction and Bases of Education in 1996, by the Brazilian Ministry of Education and Culture [43]. The Secretary of Education in Distance Education (SEED) oversees the authorization of courses to be offered via distance education. According to Muller, authorization is based on a number of criteria, including the institutional and financial objectives of the institute, qualification of the instructors, infrastructure, experience and maintenance of required accreditations. Since the passing of the Law, there has been a steady increase in distance programs being approved and offered [43]. There were nearly three million students enrolled in higher education in 2003 [43].

Distance learning has been crucial to the training of teachers through programs that can be accessed from diverse regions of the country. Especially primary level teachers have been targeted through funding known as Fundescola that will insure that teachers will have special training or be university graduates [39]. The majority of distance learning courses in the country have been for the purpose of training new teachers [43]. According to the Hughes [44] website there is a major thrust between the telecom industry and the University of Northern Parana in its endeavor to increase enrollment in the Connected Presence Teaching System (CPTS) within the many Brazilian municipalities.

In addition to teaching, distance education in Brazil has expanded to other professional disciplines. According to Reibero, Hoeschl, Bueno, and Hoffmann [45] law is another field that distance education is becoming popular in. There is a high level of satisfaction and acceptance of distance education as an 
alternative to traditional face-to-face teaching environment among Brazilian law students. According to Ronald Mota, appointed in March 2005 to head the new Brazilian Secretariat of Distance Education, the challenges in expanding distance education in the country include its relatively large physical size and large rural population [46].

Physical medicine and rehabilitation training is an area that has entered the distance education realm [47]. According to Kavamoto et al., with the help of videoconferencing and e-learning, students across the nation are being trained in physical therapy [47]. The success of these programs rests on successful coordination and co-operation of multidisciplinary teams. There are huge implications of distance education in professional fields in a country as large as Brazil. Education in the health fields can change a nation by supporting populations outside of the metropolitan areas.

This discussion of professional education in the country contrasts with statistics for the general populace. For the working-age population, secondary education is completed by less than half; about $10 \%$ of the population does not complete primary education [39, p. 15]. For Brazil, there is a connection between the two: the extensive teacher training provided through distance learning directly impacts schooling in the country.

\section{B. Russian Federation}

In contrast to Brazil's highly centralized approach, educational technologies in the Russian Federation have emerged in a variety of projects. Distance learning in tertiary institutions in the Russian Federation is described as being developed very intensively but with disparate methods [48]. As this discussion portrays, projects have included collaborations with U.S. education partners.

With limited Internet connectivity in rural areas of the Russian Federation, distance learning has employed a mix of strategies for the establishment of a distance learning center at Stavropol State Agrarian University in southern Russia [49]. Serving five Russian colleges and partnering with Maryland Cooperative Extension, the center permits videoconference presentations that supplement visits by American veterinary scientists for an exchange that benefits both countries.

In a collaborative project with Stanford University, 10 regional Russian universities used Stanford Political Science courses in international security. Evaluation research at 3 of the institutions was conducted as part of the International Initiative on Distance Learning (IDL). Research findings indicated that for international students participating in distance learning, success is related to interactive supports such as collaborative, small-group activities and active communication. In courses stressing these features, students demonstrated improvement in critical thinking and larger gains than in control groups.

\section{India}

India has seen tremendous growth in higher education institutions. Like Brazil, India has a centralized system that has included development of distance learning, addressing needs of dispersed populations. Distance programs are embedded in all levels of education, from primary grades to professional schools.

\begin{tabular}{|l|l|l|l|}
\hline Year & Colleges: General Edu & Colleges: Professional Edu & Universities \\
\hline $1950-51$ & 370 & 208 & 27 \\
\hline $1960-61$ & 967 & 852 & 45 \\
\hline
\end{tabular}




\begin{tabular}{|l|l|l|l|}
\hline $1970-71$ & 2285 & 992 & 82 \\
\hline $1980-81$ & 3421 & $3542^{*}$ & 110 \\
\hline $1990-91$ & 4862 & 886 & 184 \\
\hline $2000-2001$ & 7929 & 2223 & 254 \\
\hline
\end{tabular}

* Included institutions for post-matric courses

Excerpted from Selected Educational Statistics 2000-2001

2006-07 Annual Report of Ministry of HRD, Government of India

Table 3. Tertiary Institutions in India: Growth by Decade

According to the 2006-07 annual report of the ministry of Human Resource Development of Government of India, there are currently 369 universities in a country that had only 20 universities at the time of its independence 60 years ago. In 2004, only around 11\% of 18-24 year olds in India were enrolled in higher education compared to $82 \%$ in the United States and 20\% in Brazil [50]. There are over 11 million students enrolled in Indian universities and colleges. In 2004, India's National Institutes of Open Schooling (NIOS) ranked as the world's largest school system, with 1.4 million learners (children and adults) [51]. Programs delivered via distance learning include primary grades, secondary grades, vocational education, and life enrichment courses. Delivery includes print materials, audio programs, video, as well as some personal contact. Degree programs and academic training are offered through the Indira Gandhi National Open University (IGNOU) in 32 countries [51].

Development and management of technology are informed by the Distance Education Council (DEC), as well as standards for quality. Speaking directly to the question of access, DEC identified this challenge: low cost and low power-consuming access and networking, with the more sweeping goal of connectivity for all [51]. This goal is, in fact, scheduled to be achieved by 2009, through state-owned telecom service providers [52]. Free, high-speed broadband connections of 2MB/second are promised, and ISPs will be encouraged to route activity through the National Internet Exchange of India (NIXI). With support from NIXI and new standards for access to submarine cables, the government expects to impact utilization of in-country bandwidth. The next step will be to mandate large scale web-hosting services, so that Internet traffic from India no longer requires routing out of the country and then re-routing back.

India is poised for another round of expansion of higher education, especially through distance learning, but it is not necessarily open for foreign universities' presence. India's Parliament continues to debate whether branch campuses from non-Indian universities should be allowed to be established and, given that possibility, whether universities could take "profits" out of the country [53]. International partnerships may be the means by which Indian students gain a global education, with reciprocal learning by students in other countries. Daniel [27] confirmed that the cross-border education impact for India is negligible in number of enrollments, even with more than 100 providers operating. About a third of them are not accredited. Without benefit of cross-border or transnational delivery, Daniel predicted that India will have difficulty in meeting its own goal for distance learning: that $40 \%$ of all higher education offerings will be made through distance learning in 2010.

Of the BRIC nations, India is the best known for its internal checks on quality assurance. Supervising agencies include the National Assessment and Accreditation Council, the National Board of Accreditation, the Distance Education Council, and the All India Council for Technical Education [27].

\section{China}

More than a quarter of China's 2800 colleges and universities use distance learning as the primary 
delivery method for education. China's large population presents great potential for growth in higher education but the nation also has unique pressures in meeting the challenge, including political considerations that impact foreign institutions that may seek partnerships in cross-border education.

The tripling of China's higher education enrollment in recent years [39, 54] reflects changes beyond the obvious economic ones. Also at work was the lifting of age and marital status requirements (maximum age 25 and not married) for students. The increase in enrollments does not reflect equity, however, between poor and non-poor families or between rural and urban citizens. With higher costs associated with education (a worldwide trend not individual to China), the gap in "opportunities between the developed and underdeveloped areas is rapidly widening” [54, p. 18].

The country has more than 800 distance learning colleges, which is in addition to more than 2000 other higher education institutions [9]. Still, China sees the needs of prospective students outstripping the supply. Foreign universities have provided some of the recent new supply in the form of branch campuses located in China. Notable in-country providers are University of Nottingham (U.K.) and, from the U.S., University of Maryland, Stevens Institute of Technology (New Jersey), Fordham University (New York), University of Texas at Arlington [55]. But the cost of operating a branch campus is prohibitive for most foreign universities and, in fact, the branches in place in China are not all fully staffed or utilized. Strategies such as hybrid distance learning are used to allow for short visits by foreign faculty, followed by Internet-based learning for the remainder of the semester. Regulatory issues between the Chinese government and foreign universities are problematic, although at least some foreign universities tend to think that the great need for their presence will make those issues manageable [55].

While a response to the problems might be to simply offer more wholly online offerings to China's citizens through cross-border delivery, that model has inherent roadblocks. First, the Chinese student seeking advancement in graduate study or employment needs a degree from an institution recognized by the culture as appropriate. Most students continue to consider their own national universities as first choice, as these are the institutions that help them advance in society, including geographic residence [26]. The lure of travel abroad is great, of course, but even though internationally the number of Chinese students in America and Europe and other Asian capitals is noticeable, this number is miniscule in Chinese education statistics. In short, student mobility within Chinese society is more important for most than mobility across borders.

Finally, a roadblock to "outside" distance learning, at least in the long run, may be competition from China itself as a distance learning provider. While the nation's current number of prospective students is large, so is the number of prospective educators - and it is reasonable to assume that China's ramping up of its higher education system will include creation of a large number of distance learning providers, geared to serving the populace. We might project that foreign universities that maintain their presence in China will be those that complement the Chinese institutions and serve among the nation's community of outstanding universities - in short, the best will survive because they enhance China's offerings for the citizenry. "World-class university" standing is a goal articulated by China's projects to fund top universities to excel and gain prominence among the world's leading institutions of higher learning [55, 56].

\section{CONCLUSIONS}

Daniel [27] set five requirements for cross-border education if it is to benefit developing countries: accessibility, availability, affordability, relevance (to local priorities), and acceptable quality. Accessibility has been featured internationally since 1948 when the U.N. issued the Universal Declaration 
of Human Rights. Article 26 of the Declaration calls for equal right and access to all levels of education. This historical foundation is evident in modern nations' dedication/initiatives to promote literacy and formal education opportunities. An example in distance learning is the advent of the open universities, which serve the general populace.

Innate to the concept of accessibility are the technical considerations that include technology infrastructure; Internet penetration; cost of tertiary education to individuals and their families; costs to institution; regulation of cross-border imports and exports; boundaries characterized as flexible or rigid, permeable or closed; and students' personal tools. The scope of accessibility is broader and has considerably expanded in the 60 years since the U.N. Declaration called for equal right and access.

For the BRIC nations profiled in this paper, no conclusion about cross-border education can be drawn without a caveat that technology innovations will likely be the driving force behind delivery systems. But one conclusion about BRIC can be suggested: that India is least likely to employ cross-border educational offerings, not due to less need or less ability than any other country but due to the legislative concerns of government that already disallow and discourage importing of higher education. While India has one of the largest concentrations of elite educators and high standards for quality assurance in higher education, it is the BRIC nation most protective of its educational resources.

Briefly, the statistics and conditions outlined in this paper suggest a simple typology in Table 4 for analyzing trends in exporting and importing education. While government regulation is not accounted for in the typology, the entry for "current involvement by foreign providers" serves that purpose. The table reports on the typology categories using generalized levels (such as low, medium, high). Figure 3 portrays an even more generalized comparison of the BRIC nations in terms of what we might expect of their growth in cross-border education.

Any prediction scheme is risky when factors include the global economy and technology. Nevertheless, the general trends to date suggest that the greatest potential of cross-border education lies with China. Foreign interest, referring to the unrealized interest by outside countries, paired with current foreign providers clearly favor China as the most likely partner for cross-border delivery. High levels in these categories for China are countered by the lower rating on permeability of boundaries or borders. As we watch the development of cross-border education we are likely to see increases in all the BRIC nations, and, as predicted by many futurists, boundaries will become even more flexible and permeable.

\begin{tabular}{|l|l|l|l|l|}
\hline & Brazil & Russian Fed. & India & China \\
\hline $\begin{array}{l}\text { Internet and other network } \\
\text { infrastructure }\end{array}$ & Medium investment & Medium investment & High Investment & High Investment \\
\hline $\begin{array}{l}\text { Recent growth in tertiary } \\
\text { education }\end{array}$ & Doubled & More than doubled & $\begin{array}{l}\text { Increased more } \\
\text { than 50\% }\end{array}$ & $\begin{array}{l}\text { More than } \\
\text { tripled }\end{array}$ \\
\hline $\begin{array}{l}\text { Boundaries flexible and } \\
\text { permeable }\end{array}$ & High & High & Low & Medium to Low \\
\hline $\begin{array}{l}\text { Current involvement by foreign } \\
\text { providers }\end{array}$ & Low & Low & Low & Medium \\
\hline Number of Internet users & Higher & Higher & Low & Medium \\
\hline $\begin{array}{l}\text { Interest by foreign providers } \\
\text { based on expectation for } \\
\text { cooperation / encouragement }\end{array}$ & Medium & Medium & Low & High \\
\hline GNI [gross national income] & Higher & Higher & Low & Medium \\
\hline
\end{tabular}




\begin{tabular}{|l|l|l|l|l|}
\hline $\begin{array}{l}\text { Likelihood for change in cross- } \\
\text { border education }\end{array}$ & Medium & Medium & Low & High \\
\hline
\end{tabular}

Table 4. Typology for Comparing BRIC Nations on Cross-Border Education

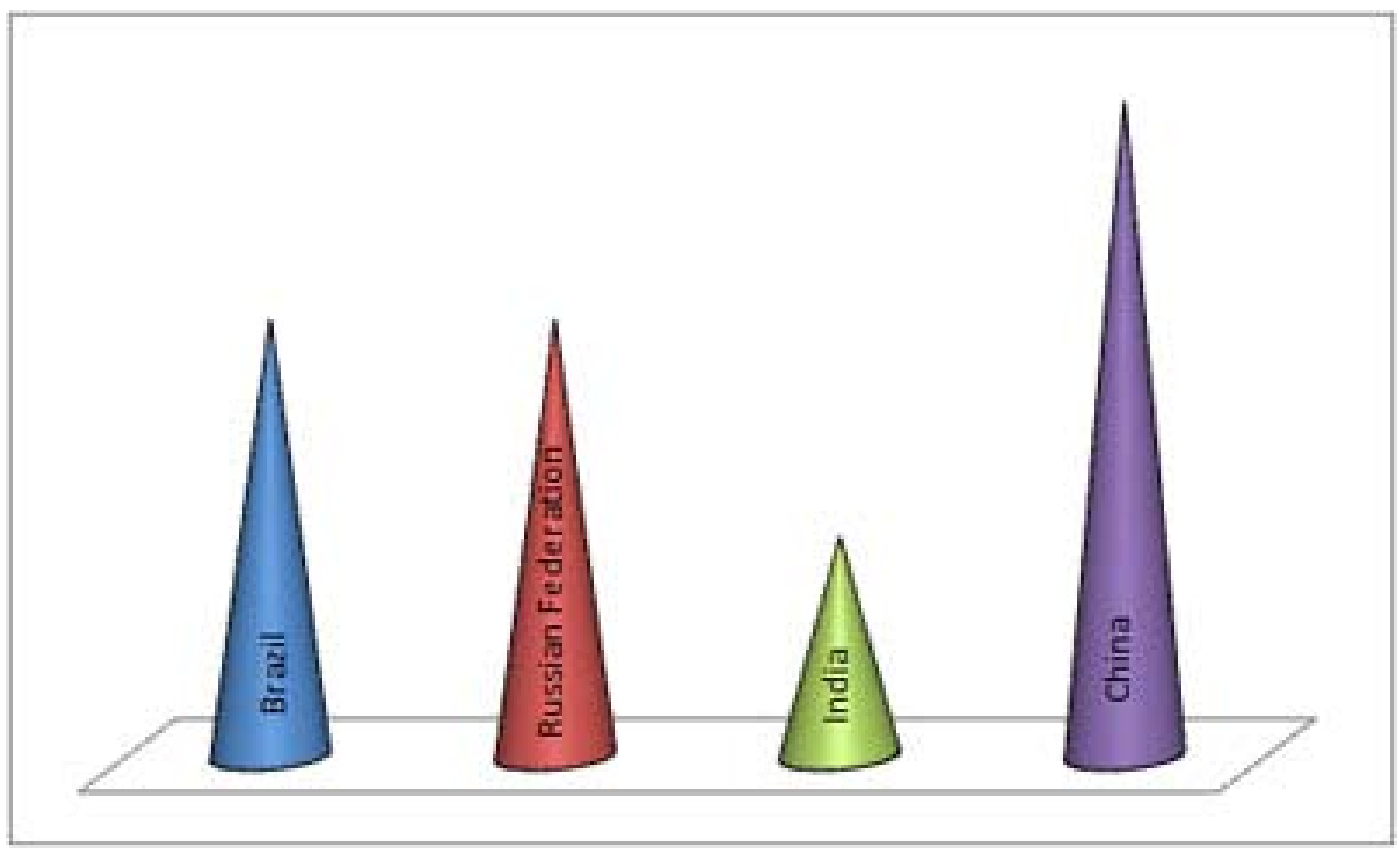

Figure 3. Potential Comparative Growth of Cross-Border Education

\section{ABOUT THE AUTHORS}

Mary Bold is an Associate Professor of Family Studies at Texas Woman's University. She co-developed an online Master's program and is currently researching aspects of academic and business continuity relating to distance learning. Dr. Bold publishes and presents in both distance learning and the family field. Queries about this article may be directed to Dr. Bold at bold@marybold.com.

Nirisha K. Garimella is a doctoral student in Family Studies at Texas Woman's University. Her research interests include culture and immigration. Ms. Garimella teaches multiculturalism, parenting, and family economics. She may be contacted at nkuchima@twu.edu.

Lillian Chenoweth is a Professor of Family Studies at Texas Woman's University. She co-developed an online Master's program and is now developing educational programs in Second Life and other Web 2.0 applications. Dr. Chenoweth publishes and presents in both distance learning and the family field. She may be contacted at lillian.chenoweth@gmail.com.

\section{RESOURCES}

- American Council on Education (ACE) Center for International Initiatives (CII): http://www.acenet.edu/Content/NavigationMenu/ProgramsServices/International/index11.htm

- Center for International Higher Education (CIHE), Boston College: http://www.bc.edu/bc_org/avp/soe/cihe/

- Center for the Study of Higher Education, Pennsylvania State University: 
http://www.ed.psu.edu/cshe/

- Commonwealth of Learning: http://www.col.org/colweb/site

- International Center for Distance Learning (ICDL), U.K. Open University: http://www-icdl.open.ac.uk/

- IMS Global Learning Consortium (IMS GLC): http://www.imsglobal.org/

- Institute for Higher Education Policy (IHEP): http://ihep.org/

- Institute of International Education: http://www.iie.org/

- International Council for Open and Distance Education (ICDE): http://icde.org/

- International Review of Research in Open and Distance Learning (IRRODL) http://www.irrodl.org/index.php/irrodl

- Observatory on Borderless Higher Education: http://www.obhe.ac.uk/

- UNESCO, The Virtual University and e-Learning: http://www.unesco.org/iiep/virtualuniversity/

- World Bank, The Global Distance Education Net (Global DistEdNet): http://www1.worldbank.org/disted/

\section{REFERENCES}

1. McMurtrie, B. The global campus. The Chronicle of Higher Education 53(26): A37, March 22007.

2. UNESCO. Education of all indicators: Expert group meeting. UNESCO Institute for Statistics, 2001. Available: http://www.uis.unesco.org/file_download.php?URL_ID=3810\&filename =10419538070EFA_report_EN.pdf\&filetype=application\%2Fpdf\&filesize=600553\&name=EFA_ report EN.pdf\&location=user-S/.

3. Knight, J. Trade in higher education services: The implications of GATS. London: The Observatory on Borderless Higher Education, International Strategic Information Service, 2002a.

4. Dikshit, H. P., S. Gang, S. Panda \& Vijayshri (Eds.). Access and Equity: Challenges for Open and Distance Learning. New Delhi: Kogan Page India, 2002.

5. Bourne, J., J. C. Moore, J. Sener, F. Mayadas \& L. F. Ettinger. Increasing access in online higher education. Journal of Asynchronous Learning Networks 10(3): 2006.

6. Hezel, R. Global e-learning opportunity for U.S. higher education: Introduction to Asia, 2005. Available: http://www.hezel.com/globalreport/IntrotoAsia.pdf.

7. Contact North. Northern Ontario’s Distance Education \& Training Network, 2007. Available: http://www.contactnorth.ca/.

8. Birchard, K. Canadian distance-education network to be expanded to Northern Ontario. Chronicle of Higher Education 52(47): A31, July 282006.

9. Gordon, J. \& Z. Lin. A journey through China. E-Learning Age: 16-18, October 2004.

10. Keegan, D. Mobile learning: The next generation of learning. The 18th Asian Association of Open Universities Annual Conference, Shanghai, November 2004. Available: http://learning.ericsson.net /mlearning2/files/Des_paper_AAOU.pdf.

11. Baggaley, J. \& B. Batpurev. The world-wide inaccessible web, part 1: Browsing. International Review of Research in Open and Distance Learning 8(2): 2007.

12. Baggaley, J., B. Batpurev \& J. Klaas. The world-wide inaccessible web, part 2: Internet routes. International Review of Research in Open and Distance Learning 8(2): 2007.

13. Sharing quality higher education across borders. Document issued by the International Association of Universities (IAU), the Association of Universities and Colleges of Canada (AUCC), the American Council on Education (ACE), and the Council for Higher Education Accreditation (CHEA). International Higher Education 39: 3-6, Spring 2005.

14. Miller, D. C., A. Sen, L. B. Malley \& E. Owen. Comparative indicators of education in the United 
States and other G-8 countries: 2006. Washington, DC: National Center for Education Statistics, 2007.

15. Woo, S. Several other countries outpace U.S. growth in international students. The Chronicle of Higher Education: October 17, 2006.

16. Labi, A. Chinese enrollments drop in Britain. The Chronicle of Higher Education 52(11): A49, 2005.

17. Labi, A. Foreign students increase in Britain. The Chronicle of Higher Education 53(5): A44, September 22, 2006a.

18. British Council. Study in your own country: Why study for a U.K. qualification in your own country? 2007. Available: http://www.educationuk.org/.

19. MacLeod, D. \& L. Ford. On the brink of a revolution. The Guardian: February 28, 2006. Available: http://education.guardian.co.uk/students/overseasstudents/story/0,1719178,00.html.

20. Jung, I. Changing faces of open and distance learning in Asia. International Review of Research in Open and Distance Learning 8(1): 2007.

21. American Council on Education. U.S. update on the GATS negotiations and issues for higher education: March 2007. Available: http://www.acenet.edu/AM/Template.cfm?Section=Home \&Template=/CM/ContentDisplay.cfm\&ContentFileID=2806.

22. Knight, J. Trade creep: Implications of GATS for higher education policy. International Higher Education 28: 5-7, Summer 2002b.

23. Robinson, D. GATS and the OECD/UNESCO guidelines and the academic profession. International Higher Education 39: 6-7, Spring 2005.

24. Sorensen, O. GATS and education: An "insider" view from Norway. International Higher Education 39: 7-9, Spring 2005.

25. Hallak, J. \& M. Poisson. Corrupt schools, corrupt universities: What can be done? Paris: International Institute for Education Planning, 2007.

26. Ding, H. Students at a Chinese radio and television university: Reasons for participation, and perceptions of their status as students and the quality of their learning. Unpublished dissertation, Northern Iowa University, UMI Number: 3222547, 2006.

27. Daniel, J. S., A. Kanwar \& S. Stamenka Uvalić-Trumbić. Mega university = mega quality? Address at the 2nd World Summit of Mega-Universities, 25 September 2005, New Delhi.

28. UNESCO/OECD. Governing Board of the Centre for Educational Research and Innovation Guidelines for Quality Provisions in Cross-Border Higher Education, 2003. http://www.oecd.org/dataoecd/27/51/35779480.pdf.

29. Altbach, P. G. Knowledge and education as international commodities: The collapse of the common good. International Higher Education 28: 2-5, Summer 2002.

30. Green, M. \& M. Baer. Global learning in a new age. The Chronicle of Higher Education B24: November 9, 2001.

31. Daniel, J. S. Mega-universities and knowledge media. London: Routledge, 1996.

32. Jung, I. Quality assurance survey of mega universities. In C.McIntosh \& Z. Varoglu (Eds.), Perspectives on Distance Education: Lifelong Learning and Distance Higher Education, 79-96. Paris: UNESCO, 2005.

33. UNESCO Mega universities, 2005. http://portal.unesco.org/education/en/ev.php-URL ID=42857 \&URL_DO=DO_TOPIC\&URL_SECTION=201.html.

34. Moloney, J. and B. Oakley. Scaling online education: Increasing access to higher education. Journal of Asynchronous Learning Networks 10(3): July 2006. http://www.sloan-c.org/publications/jaln /v10n3/v10n3_2moloney.asp.

35. IEA. Second information technology in education study module 2. International Association for the Evaluation of Educational Achievement, n.d. http://www.iea.nl/sites-m2.html.

36. National Center for Education Statistics. Comparative indicators of education in the United States and other G-8 countries: 2006. [NCES 2007-006]. 2007.

37. UNESCO. International Standard Classification of Education ISCED 1997, November 1997. http://www.unesco.org/education/information/nfsunesco/doc/isced 1997.htm. 
38. United Nations’ Provisional Central Product Classification. http://unstats.un.org/unsd/cr/registry/regcs.asp?Cl=9\&Lg=1\&Co=92.

39. UNESCO Institute for Statistics. Education trends in perspective: Analysis of the World Education Indicators, 2005. http://www.uis.unesco.org/TEMPLATE/pdf/wei/WEI2005.pdf.

40. Altbach, P.G. The rise of pseudouniversities. International Higher Education 25: Fall 2001. http://www.bc.edu/bc_org/avp/soe/cihe/newsletter/News25/text001.htm.

41. UNESCO. World education indicators, 2007. http://www.uis.unesco.org/ev.php?URL_ID=3767 \&URL_DO=DO_TOPIC\&URL_SECTION=201.

42. Litto, F. The hybridgization of distance learning in Brazil: An approach imposed by culture. International Review of Research in Open and Distance Learning 2(2): 1-14, 2002.

43. Muller, S. Distance learning in higher education: A comparative analysis of universities in Brazil and the United States. Unpublished thesis. University of Texas at El Paso, UMI Number: EP10592, 2004.

44. Hughes. Distance learning grows up in Brazil, 2007. http://www.hughes.com/HUGHES/Rooms /DisplayPages/LayoutInitial?Container=com.webridge.entity.Entity\%5BOID\%5B33B5E4F6F5372C 4791B01B0A7EC1432D\%5D\%5D\&pageid=page00000904.

45. Ribeiro, E. B. Q., H. C. Hoeschl, T. C. D. Bueno \& S. Hoffmann. A Brazilian experience on technological distance and learning for law students and professionals. $18^{\text {th }}$ BILETA Conference: Controlling Information in the Online Environment: London, April 2003.

46. Training Press Release. Simulacra’s founder working with Brazilian Government on Distance Education policies, 2005. http://www.trainingpressreleases.com/newsstory.asp?NewsID=1469.

47. Kavamoto, C. A., C. L. Wen, L. R. Battistella \& G. M. Bohm. A Brazilian model of distance education in physical medicine and rehabilitation based on videoconferencing and Internet learning. Journal of Telemedicine and Telecare 11(1): 80-82, 2005.

48. Distance learning students in Russia reflect benefits of IIS/SCIL collaborative study. Stanford Center for Innovations in Learning, Stanford University, n.d. http://scil.stanford.edu/news/russia10.htm.

49. Townsend, P. University helps develop distance learning center in southern Russia. Outlook Online. University of Maryland. February 20, 2007. http://www.outlook.umd.edu/article.cfm?id=2426.

50. Department of Higher Education, Government of India. National level educational statistics-At a glance, 2007. http://www.education.nic.in/stats/Pocket(As\%20on\%2017.04.2007)glance.pdf.

51. Annual Report 2006-2007. Department of Higher Education, Ministry of Human Resource Development. Delhi, 2007.

52. Broadband to go free in 2 years. The Economic Times. April 26, 2007.

53. Selingo, J. International deals carry potential for 'sleaze.' The Chronicle of Higher Education 53(26): A40, March 2, 2007.

54. Yang, R. Lost opportunities in the massification of higher education in China. International Higher Education 28: 16-18, Summer 2002.

55. Mooney, P. The wild, wild east: Foreign universities flock to China, but are there riches to be made, or just fool's gold? The Chronicle of Higher Education 52(24): A46, February 17, 2006.

56. Mohrman, K. World-class universities and Chinese higher education reform. International Higher Education 39: 22-23, Spring 2005. 